\title{
The possible conflict of interests existing during the exercise of the mandate of administrator or for the position of shareholder of a company by shares regulated according to law no. 31/1990
}

\author{
Andreea STOICAN \\ Bucharest Academy of Economic Studies, Bucharest, Romania
}

PICBE |

1172

\begin{abstract}
In order to prevent putting personal interests above the interest of the companies they manage, the legislator provided a set of legal rules of limitations of the management bodies' and shareholders' behavior. As such, the conflict of interests can occur either at the exact moment of their nomination in the position of management, either during the exercise of their mandate. Therefore, for such decisions that take into account personal matters, to be avoided, the legal rules contain very particular provisions in order to avoid such circumstances of acting in the detriment of the company, either through limitations of the mandate, either through very strict sanctions, including the incrimination of such deeds.
\end{abstract}

Key-words: administrator, mandate, shareholder, conflict of interests, incrimination

\section{Introduction}

In order to prevent putting personal interests above the interest of the companies they manage, the legislator provided a set of legal rules of limitations of the management bodies' and shareholders' behavior. As such, the conflict of interests can occur either at the exact moment of their nomination in the position of management, either during the exercise of their mandate. Therefore, for such decisions that take into account personal matters, to be avoided, the legal rules contain very particular provisions in order to avoid such circumstances of acting in the detriment of the company, either through limitations of the mandate, either through very strict sanctions, including the incrimination of such deeds.

A conflict of interests represents a situation in which a person has a number of interests, such as financial, economic, personal, or other interests, that can significantly affect the making of fair and impartial decisions by that person or organization in the work it performs. The presence of a conflict of interests does not automatically lead to making incorrect decisions.

Therefore, we can say that a conflict of interests represents a set of circumstances where there is a risk that professional judgment or actions relating to a principal interest will be unduly influenced by a secondary interest. As such, the main interest relates to the main activity objectives, as for example the business partners, consumer protection etc., while the secondary interest includes personal benefit that is not necessarily limited to financial gain, but can also consist in other reasons (such as family and friends favors). These secondary interests are not automatically treated as a negative element of their own, but become unacceptable if they affect the main interest.

The conflict of interests can exist either in the private or the public sector. For example, the rules on conflict of interests in the public area focus mainly on financial relations, as they are more objective and quantifiable, and usually involve the political, legal or medical environment. 
On the other hand, in the private field, the most common circumstance of conflict of interests tends to appear in the decision-making process of the administrative bodies of companies, although the activity of the shareholders' is not spared.

As mentioned above, the conflict of interests can exist either at the moment when the administrative bodies are named, either during the execution of their mandate, while exercising the powers given to them by law.

The reason for regulating such situations of conflict of interests is that of respecting the loyalty obligation that the members of the administration bodies have towards the company, together with the interest of the company that they must exclusively follow.

\section{Conflicts of interests occurred at the moment the members of the administrative bodies are named}

The first clear provision regarding a possible circumstance of conflict of interests is stated in article $153^{17}$ from Law no. 31/1990 on companies ${ }^{1}$, related to the companies by shares. Before being appointed director or manager, respectively a member of the directorate or of the supervision board in a joint stock company, the nominated person shall inform the body of the company responsible for his appointment of any relevant issues regarding certain particular issues.

On the other hand, according to the provisions of article $153^{15}$ from Law no. 31/1990 on companies, the directors of a joint stock company in the unitary system and the members of the directorate in the dualist system will not be able, without the authorization of the board of administration, respectively the supervision board, to hold the position of directors, administrators, members of the directorate or the supervision board, censors or, as the case may be, internal auditors or associates with unlimited liability in other competing companies or with the same object of activity, nor can they exercise the same or a competing trade on their own or for another person. The sanction for such matters is their revocation and liability for damages. As such, the authorization of the board of administration should take the form of a decision of this body, with all the necessary formalities imposed on it by law, under the sanction of revocability and payment of damages, and not the nullity of the mandate contract. ${ }^{2}$

A natural person may exercise at the same time no more than 5 mandates of administrator or member of the supervision board of joint stock companies whose headquarters are situated in Romania. The same provision shall apply equally to the natural person administrator or member of the supervision board, as much as to the natural person permanent representative of a legal person that is in itself an administrator or a member of the supervision board.

This prohibition though, does not refer to cases where the person elected in the board of administration or in the supervision board owns at least one quarter of the company's total shares or is a member of the board of administration or in the supervision board of a company by shares that holds the shown percentage of shares.

\footnotetext{
${ }^{1}$ Law no. 31/1990 on companies, in force since the $17^{\text {th }}$ of December 1990, republished in the Official Monitor of Romania Part I, no. 1066 from the $17^{\text {th }}$ of November 2004

2 Bodu, Sebastian, Legea societăților comentată și adnotată. Ediția 2017, Rosetti International Publishing House, Bucharest, 2017, p. 824
}

DOI: 10.2478/picbe-2019-0103, pp. 1172-1179, ISSN 2558-9652| Proceedings of the $13^{\text {th }}$ International Conference on Business Excellence 2019 
The person who breaches the above-mentioned rules is obliged to resign from the positions of a member of the board of administration or of the supervision board that exceed the maximum number of mandates, within one month of the occurrence of the incompatibility situation. Upon the end of this period of time, he will lose his mandate by exceeding the legal number of mandates in the chronological order of appointments and will also be forced to return to the company in which he exercised this mandate, the remuneration and other received benefits. However, the decisions and the debates he took part in during the exercise of the mandate will remain valid.

As we can see, all the interdictions that were supposed to be imposed in such a case disappear, as the person's in discussion only obligation is limited only to the obligation of informing the other members about his situation, which is considered enough. ${ }^{3}$

Therefore, for the members of the board of administration or the supervision board, we can only talk about an obligation of information, and not of approval, as it is the case of article $153^{15}$ from Law no. 31/1990, where it is asked, exclusively, for the directors of joint stock companies administrated in the unitary system and the members of the directorate of joint stock companies administrated in a dualist system.

Despite the information given on the number of mandates of administrator or member of the supervision board that a person can exercise at a certain moment, when he is also nominated for a new position of such representative, assigning him supposes the assumption, by the shareholders, of the risk that the company will be exposed to a conflict of interests. These conflicts will be, though, sanctioned according to the provisions applicable to the mandate the person in question exercises, no matter whether he has or has not informed the general assembly.

\section{Conflicts of interests occurred during the exercise of the mandate of the members of the administrative bodies}

It is not only the special regulation that provides, in the Romanian law, the interdiction of the existence of a conflict of interests, but even the general law itself, through article 215 from the Civil Code. As such, it is null the legal act concluded with the breach of the interests of the legal person by a member of the administrative bodies if the latter, his spouse, ascendants or descendants, collateral relatives or his relatives, up to the fourth degree included, had an interest in concluding that act and if the other party knew or ought to know about this.

When the person who is part of the administrative bodies of the legal person or one of the above-mentioned connected persons have an interest in a matter subjected to the decision of these bodies, it shall notify the legal person and shall not take part in any deliberations concerning it. Otherwise, they will be responsible for the damages caused to the legal entity, unless without their vote the required majority could not have been obtained.

According to the dispositions of article $144^{1}$ of Law no. 31/1990, the members of the administrative board will exercise their mandate with the care and diligence of a good manager.

\footnotetext{
3 Catană, Radu Nicolae, Dreptul societăților comerciale. Probleme actuale privind societățile pe acțiuni. Democrația acționarială, Sfera Juridică Publishing House, Cluj-Napoca, 2007, p. 174
} 
The administrator does not violate the obligation stipulated above if, when taking a business decision, he is reasonably entitled to consider that he is acting in the best interest of the company and on the basis of appropriate information.

These conflicts of interests on behalf of the administration bodies are tempted to give place to certain abuses in the exercise of their mandate. That is the reason for which the shareholders must always pay attention to the way the company is administrated.

The contradictory interests affect the objectivity of the decision and, as such, it affects PICBE | the good-faith of the members of the administrative body towards the company they manage and legally represent.

The conflict of interests can intervene either in the decision-making process, either in the representation activity.

As far as the decision-making process is involved, the administrator who, in a particular matter, directly or indirectly, has interests contrary to the interests of the company, must notify the other administrators, censors and internal auditors and not take part in any deliberations concerning this operation. The same is the situation for the members of the supervision board. ${ }^{4}$

The purpose of informing the persons mentioned above, respectively the members of the management board, the censors or the internal auditors, is, first of all, that of eliminating the influence that the person with contradictory interests could have upon the decision, through his biased position. The double formality of information on the matter is complete, absolute, certain and expressed. That is why it needs to be made during the meeting of the administration board, before the beginning of the debates on the matter in question and also, afterwards, mentioned in the report of the meeting. For the censors and the internal auditors, it should be made in written form.

The annual fulfillment of the declaration of interests does not relieve the person from his obligation to inform the necessary persons of his situation when the matter should be approved or is on the agenda for the approval, but its only purpose is that of the management of the company, through its censors and internal auditors, to be aware of a potential future occurrence of a conflict of interests.

Notifying the censors or the internal auditors is only informative and does not imply the need to be approved or qualified and interpreted as contrary to the interests of the company. Therefore, the censors and the internal auditors do not have to approve, disapprove, validate or invalidate or have any kind of expressed opinion over the situation of conflict of interests they were notified upon by a member of the administrative bodies. As such, this position is irrelevant from the perspective of an applicable sanction to the member of the management body who breaches such legal provisions.

The relevant aspects of the contradictory interest of the person who should have refrained from certain actions will only be appreciated by the judge, after the causal link between the deed and the injury is established, during the trial on the action of civil liability brought to court by the company itself. The member of the administrative body is not, though, at the moment of informing about the conflict of interests before he refrains from certain actions, to reveal what the contradictory interest implies.

\footnotetext{
${ }^{4}$ Article $144^{3}$ paragraph 1 corroborated with article $153^{8}$ paragraph 3 from Law no. 31/1990 on companies. The same obligation applies to the administrator also if, in a particular operation, he knows that his spouse or his relatives up to the fourth degree have a certain interest in the matter.
} 
In what implies the representation, the regulation of the conflict of interests will be that of article 215 from the Civil Code. Many times, the damaging effects on the company are produced through a conflict of interests that affects the relation between the representative and the one who is represented. The representative is tempted to put his interest above the interest of the company. The contradiction of interests is regulated by article 1303 of the Civil Code, which states that the contract concluded by a representative in conflict of interests with the one he represents may be annulled at the request of the latter, when the conflict was known or ought to have been known by the contractor at the conclusion of the contract.

The existence of a contradictory interest towards the interest of the company is presumed when the member of the administration body concludes a contract with himself (autocontract). Also, it is presumed that a potential conflict of interests is known by the representative administrator when the interest belongs to a family member, but in such a case, the presumption will be relative, the administrator having the possibility to prove the contrary or the fact that, even though such a contradictory interest exists, he did not know about it or even he did not know about the relation of kinship.

The legal presumption of fraud of the interests of the represented company is also relative. The contradiction of interests is not forbidden, but it needs to be identified in order to be verified. As such, the presumption of fraud equals with a presumption of bad-faith which could be eliminated when the action was, despite the conflict of interests, missing or impossible, so that there are no reasons to ask for the nullity of the act. The obligation to bring evidence for not causing any damage to the company's interest belongs to the representative, who has to prove his good-faith.

\section{Conflict of interests existent during the decision making process by the shareholders of a company by shares}

Article $136^{1}$ from Law no. 31/1990 imposes an essential obligation on the shareholders, respectively that of exercising all their rights in good-faith, by respecting the rights and the lawful interests of the company and of all the other shareholders.

Also, article 127 from the same legal act establishes an important rule for the exercise of the right to vote in general shareholders' meetings, and that is the principle of abstention from voting when the shareholder is in a conflict of interests. The foundation of such a principle can only be understood by reference to another essential principle for the matter of companies, which is the principle of good-faith of the shareholders established by the above-mentioned article $136^{1}$ of the Law no. 31/1990.

Abstaining from voting is not just a personal option, but even an obligation, as the legislator understood to give priority to the company's interest. The state of conflict of interest provided by article 127 of the Law no. 31/1990 is one that imposes a certain behavior both on the shareholder concerned in the sense of refraining from deliberation and automatically from voting, but also, it does not exclude the possibility of the other shareholders who may raise the conflict of interests situation in which one of the shareholders is. As such, they may record it in the report of the general meeting, so that the failure to take into account the votes of the shareholder in this state of conflict will not 
constitute grounds for the annulment of the general meeting of the shareholders' decision so adopted. ${ }^{5}$

The state of conflict of interests, provided by article 127 , is one that requires both the conduct of the shareholder concerned in the sense of refraining from deliberation and automatically from voting. Though, it does not exclude any diligence from other shareholders that may raise to attention the conflict of interest situation one of the other shareholders' finds himself into. Abstaining from voting is not just a personal option, but more of an obligation, as the legislator understood to give priority to the company's interest.

As mentioned above, the non-observance of the prohibition regulated by article 127 does not, in principle, invalidate the general meeting of the shareholders' decision taken with the vote of the shareholder in conflict of interests, but only his obligation to pay damages, if the majority of the required voting quorum has been formed by his vote. Although, we consider that, according to article $136^{1}$ from Law no. 31/1990, we cannot exclude the annulment of the decision taken with the vote of a shareholder in conflict with the company either, if that vote was the result of a majority abuse.

Also, the annulment of a general meeting of the shareholders' decision does not exclude the involvement of the civil liability of the shareholder who has voted decisively for the decision, but in bad-faith, abusively using its majority position in the shareholding of a company.

Even as such, we are convinced that article 127 of Law no. 31/1990, therefore, mainly has a preventive role, because otherwise, if the idea of accepting the vote of a shareholder in conflict of interests is allowed only because there are potential future remedies, it would come to the situation where a legal norm would be without effect.

Regarding the issue of the conflict of interests between the shareholder and the company, as it is not particularly mentioned, we understand that article 127, that provides the principle of abstaining from voting if the shareholder is in conflict of interests which applies personally, also applies if he acts as a representative of another shareholder.

From this perspective, we realize that there are two aspect to clarify about this obligation of the shareholders. Firstly, which is the legal nature of the situation created by article 127 from Law no. 31/1990 and secondly, whether that law forbids the right of that particular shareholder who finds himself in a potential conflict of interests to participate in the general meeting or only the right to participate in a particular decision within the general meeting.

Regarding the first aspect, we need to understand that the abstention of the right to vote of the shareholder can be interpreted either as a limitation, a prohibition or a suspension.

\footnotetext{
${ }^{5}$ As such, for example, the Court of law decided to reject the complaint initiated by the plaintiff, one of the shareholders of the company, when he asked for the absolute nullity of the decision of the shareholders' general meeting in which they were going to debate and vote upon the dismissal of the members of the administration board from which his wife was a member of. The agenda included the revocation of the members of the administration board to which the plaintiff's wife belonged, and also the liability to those members. The plaintiff's argument was that he was impeded by his fellow shareholders to vote and exercise his legal right in his quality of partner in the company. Not only did the Tribunal, as first court reject his action, but also the Court of Appeal, in the appeal, on the ground of lack of reasoning for invoking the absolute nullity, cumulated with the fact that his right to vote was not violated by minority shareholders, the complainant being the one who did not comply with the provisions of article 127 and $136^{1}$ of Law no. 31/1990. Therefore, the suspension of the right to vote cannot even be called into question, but only its refusal by the other shareholders to participate in the deliberations on the revocation of the administration board. (Court of Appeal from Craiova, Decision no.690 from the 20th of September, unpublished)
}

DOI: 10.2478/picbe-2019-0103, pp. 1172-1179, ISSN 2558-9652| Proceedings of the $13^{\text {th }}$ International Conference on Business Excellence 2019 
Leaving aside the differences in the ways of the interpretations offered, which are partly irrelevant in terms of effects, we appreciate that the provision is imperative, therefore we are in the presence of a prohibition of such a right. ${ }^{6}$

Regarding the second aspect, there is a problem whether we should consider that the person in question is to be taken into consideration for the establishment of the attendance quorum for that general meeting of the shareholders or not. On one hand, we could say that since he is not allowed to vote on that certain matter, he shouldn't even be taken into PICBE | consideration for counting the quorum. It, therefore, makes no sense for someone to be taken into consideration for the quorum, since he does not have the possibility vote or participate in the debates. On the contrary, if he were to count for the quorum, we could create an impossibility to reach a decision for the needed majority for the vote, as the quorum he is part of will need to be bigger.

On the other hand, the shareholder, though, could participate in the meeting and may vote on other items on the agenda. He should, though, refrain from deliberations on that operation where he is forbidden to vote, or even participate in the debates about the issue in question, as he should not represent any kind of influence in the future decision the other shareholders are going to take.

As such, we are tempted to say that the voting rights of such a shareholder should be taken into account, attendance quorum included, only when establishing the quorum for that general meeting of the shareholders for other matters, but not for the issue in which there exists a possible contradictory interest.

\section{Conclusions}

As we can see from all mentioned above, taking certain decisions or abstaining from voting is not just a personal option, but more of an obligation, as the legislator understood to give priority to the company's interest.

The existence of the company is the result of the will of the shareholders expressed both at the moment of its establishment and later during its existence. Therefore, the shareholders are animated by a personal interest. It is true that at the moment of signing the constitutive act there is a consensus that can be explained and understood through the existence of the specific elements of the company's contract - the contribution of the associates, affectio societatis, obtaining and sharing the benefits. But, as it can be seen, all those initial actions, at that moment have a general character, without materializing in concrete actions, except those necessary for obtaining the legal personality. It is only after this moment that the shareholders or the initial and future administrative bodies will express their individuality, therefore the contradiction of interests could arise. The structure of the company is always dynamic, it fluctuates as a result of the will of all the persons managing it.

Therefore, the fact that they can have opposite interests is a truth that we must accept, especially as between shareholders there is a permanent struggle to satisfy their own

\footnotetext{
${ }^{6}$ The legislator usually, in other legal provisions, stipulates clearly when it is a suspension or limitation of the voting right, such is the case, for example, of article 101 from Law no. 31/1990, which provides the following: "the constitutive act can limit the number of votes of the shareholders that own more than one share" (paragraph 2) or that "the exercise of the right to vote is suspended for the shareholders who are not aware of the maturity payments" (paragraph 3).
} 
interest. That is why certain regulations of general principles, rules designed to ensure a functional balance of the structure were needed.

The loyalty obligation is the foundation upon which the conflict of interests arises. Loyalty must be the basis of any legal action taken by the shareholder or administrator. The obligation to act with loyalty, as part of the principle of good-faith, is justified by the primal role of the economic interests of the company. In some ways the success of the organization as a whole depends on the relationship that exists between the partners, the equilibrium that is created for the achievement of the common purpose, namely the gain of benefits.

The observance of the loyalty obligation by the shareholders and the administrators requires them to act, both within the company and in relations with third parties, impartially and honestly, in order to optimize the interests of the company and the avoidance of conflicts of interest.

Even as such, what we would like to emphasize is the subjective character of the loyalty obligation. As we said above, it is an essential part of the good-faith principle. However, no one can deny the fact that the extent or the features of the loyalty obligation are quite subjective. Therefore, while pursuing the good-faith of a person, even when they are one of the managing partners of an important entity such as a joint stock company, is to be referred to certain standards. Even in the situation in which damages are caused through a certain action or decision of one of the management bodies, it cannot directly lead to the conclusion that this obligation is being breached.

\section{Bibliography}

Bodu Sebastian, Legea societăților comentată și adnotată, Ediția 2017, Rosetti International Publishing House, Bucharest, 2017;

Bodu Sebastian, Limitări și conflicte de interese la numirea și în exercitarea mandatului de administrator al unei societăți comerciale, in Revista Română de Dreptul Afacerilor no. 12/2015, p. 63-98;

Catană, Radu Nicolae, Dreptul societăților comerciale. Probleme actuale privind societățile pe acțiuni. Democrația acționarială, Sfera Juridică Publishing House, Cluj-Napoca, 2007;

Călin Dragoș, Administrarea și conducerea societăților de investiții, in Revista Română de Dreptul Afacerilor no. 9/2013, p. 101-127;

Civil Code of Romania, republished in the Official Monitor of Romania Part I, no. 505 from the 15 th of July 2011 ;

Law no. 31/1990 on companies, in force since the $17^{\text {th }}$ of December 1990, republished in the Official Monitor of Romania Part I, no. 1066 from the 17th of November 2004;

Munteanu Emanoil, Regimul juridic al administratorilor societăților comerciale, All Beck Publishing House, Bucharest, 2000;

Piperea Gheorghe, Obligațiile și răspunderea administratorilor societăților comerciale, All Beck Publishing House, Bucharest, 1998;

Titus Prescure, Repere ale evoluției modalităților dreptului de vot în adunările generale ale asociaților societăților reglementate de Legea $n r .31 / 1990$ privind societățile și de Legea nr. 297/2004 privind piața de capital, in Revista Română de Dreptul Afacerilor no. 7/2016, p. 21-36; 